\title{
Skeletal Muscle Tissue
}

National Cancer Institute

\section{Source}

National Cancer Institute. Skeletal Muscle Tissue. NCI Thesaurus. Code C13050.

Striated muscles that are under voluntary control of the organism. They are connected at either or both ends to a bone and are utilized for locomotion and other movements. 